\title{
Analisis Persepsi Masyarakat Dengan Sikap Memilih Pengobatan Tradisional Lo $i$ Keta Dari Pada Ke Rumah Sakit Di Era Pandemi Covid-19
}

\author{
${ }^{1}$ Junaidin*, ${ }^{2}$ Sri Yuliana, ${ }^{3}$ Arif Rahman \\ ${ }^{1,2,3}$ Sekolah Tinggi Ilmu Kesehatan Yahya Bima \\ *Email : junaidinstikesyahya.com
}

Kata kunci :

Persepsi, Sikap, Loi

Keta. Covid-19.

Keywords:

Perception,

Attitude, $L o$ ' $i$

Keta, Covid-19.

\section{Info Artikel:}

Tanggal dikirim:

11 November 2021

\section{Tanggal direvisi:}

1 Desember 2021

Tanggal diterima :

9 Desember 2021

DOI Artikel:

10.33862/citradelim a.v5i2.261

Halaman: 72-77

\section{Abstrak}

Era Pandemik Covid-19 mengubah perilaku masyarakat mencari pengobatan alternatif untuk meningkatkan daya imunitas tubuh dalam pencegahan penularan covid-19. Loi Keta merupakan obat tradisional yang dipercayai masyaraktat sebagai pencegahan dan pengobatan berbagai macam penyakit serta dapat meningkatakan imunitas tubuh saat pandemi covid-19. Penelitian ini untuk menganalisis persepsi dan sikap masyarakat dalam memilih pengobatan tradisional Loi Keta saat pandemi covid-19. Penelitian ini adalah penelitian kualitatif menggunakan purposive sampling, sampel sebanyak 15 partisipan. Hasil: Kembalinya perilaku konsumsi obat tradisional Lo'i Keta saat pandemi covid-19, karena takut tertular covid di fasilitas kesehatan. Loi keta dipercaya dapat meningkatkan imunitas tubuh, aman digunakan dan mudah didapatkan oleh masyarakat. Pemanfaatan Loi Keta dipercayai masyarakat sebagai pencegahan dan pengobatan penyakit kulit, bisul (Furunkel), cacat air (varicella), Gastritis, Liver, Cancer dan demam serta meningkat imunitas antibodi. Cara penggunaan obat tradisional Loi Keta yaitu diminum, dikunyah dan dibaluri pada lokasi yang sakit. Optimalisasi penggunaan obat tradisional Loi Keta perlu di uji laboratorium untuk mengetahui kandungan pada Loi Keta.

\section{Community perception analysis with the Attitude of choosing treatment} tradisional Lo'i Keta instead of going to the Hospital in the Covid-19 pandemic era in Woja District, Dompu Regency.

\section{Abstract}

Covid-19 pandemic era change people's behavior looking for alternative medicine to increase body immunity in prevention Covid-19 transmission. Lo'i Keta is tradisional medicine trusted by society as prevention and treatment various diseases and increase the body's immunity moment Covid-19 pandemic. This research to analyze perception and people's attitudes in choosing treatment traditional Lo'i Keta during the Covid-19 pandemic. The research is qualitative using purposive sampling. A sample of 15 participants. Results: return of behavior drug consuption traditional Lo'i Keta during the Covid-19 pandemic, for fear infected with covid in healt facilities. Lo' $i$ Keta can be trusted increase body immunity, safe to use and easy to get by society. Utilization of Lo' $i$ Keta trusted by society as prevention and treatment skin disease, boils (furucles), water defect (varicella) Gastritis, Liver, Cancer, Fever and increase antibody immunity. How to use Lo' $i$ Keta that is drink, chewed and covered at the site of the disease. Usage optimazation Lo' $i$ Keta tradisional medicine need to be tested in the laboratory to find out the content of Lo'i Keta. 


\section{PENDAHULUAN}

Indonesia memiliki kekayaan sumber daya alam yang telah dimanfaatkan sebagai obat tradisional turun temurun. Obat tradisional merupakan pengetahuan, keterampilan dan praktek masyarakat berdasarkan teori, keyakinan dan pengalaman adat budaya berbeda yang digunakan dalam menjaga, mencegah, mendiagnosa, atau mengobati penyakit fisikdan mental. Pengobatan tradisional berbasis kearifan lokal (lokal wisdom) dapat meningkatkan taraf kehidupan baik secara ekonomi maupun kesehatan masyarakat. Jika masyarakat mampu memanfaatkan pengobatan tradisional maka akses masyarakat terhadap pengobatan pada saat mengalami gangguan kesehatan semakin mudah karena disesuaikan dengan kemampuan daerah atau lokal untuk menangani masalah kesehatan (Purnama, 2016).

Perilaku promosi, pencegaha, pengobatan dan pelayanan kesehatan sangat erat hubungannya dengan respon masyarakat terhadap sakit. Respon masyarakat terhadap sakit biasa terjadi antara lain, tidak bertindak tidak melakukan kegiatan (no action), tidakan mengobati diri sendiri (self treatment), mencari pengobatan pada fasilitas pengobatan tradisional (traditional remedy), dan mencari pengobatan pada fasilitas Rumah Sakit atau Puskesmas (Adventus et al., 2019).

Sikap perilaku pengobatan menggunakan obat tradisional merupakan salah satu perilaku kesehatan. Health Belief Model (HBM) digunakan dalam perilaku preventif perilaku sehat dan respon perilaku terhadap pengobatan yang akan dilakukan, dengan fokus pada sikap dan kepercayaan (belief) pada individu. Konsep dasar Health Belief Model (HBM) merupakan perilaku kesehatan ditentukan oleh kepercayaan individu atau persepsi tentang penyakit dan cara untuk mengurangi kejadiannya. Penggunaan Health Belief Model (HBM) dapat diaplikasikan dalam menjelaskan perilaku pencarian pengobatan (Nelson, 2018).

Era Pandemi Covid-19 muncul berita-berita tentang pengobatan secara tradisional untuk meningkatkan daya tahan tubuh sebagai bentuk upaya pencegahan tertular Covid-19. Hal ini dapat mengarahkan masyarakat beralih kepada pengobatan tradisonal seperti obat tradisional Lo'i Keta yang merupakan hasil produk kesehatan lokal masyarakat Bima dan Dompu. Lo'i Keta. Merupakan ramuan obat yang dibentuk bulatan kecil-kecil berwarna putih keunguan yang terbuat dari tepung beras ketan putih, beras merah, ketan hitam, kulit pohon duwet, daun bidara, bunga, buah dan daun delima, bunga pacar, wunta (bunga) parmau keta, wunta mundu, daun katu, kulit manggis, wunta kenanga, dan lainnya data ini dari masyarakat pembuat Lo'i Keta (Anonim, 2019).

Masayarakat Bima-Dompu sejak dulu sudah menggunakan pengobatan tradisional Lo'i Keta untuk mengobati berbagai macam penyakit mulai penyakit ringan hingga penyakit berat. Cara penggunaan cukup mudah, ada yang dibalurkan pada bagian yang sakit seperti pada sakit mata, bisulan, kawaro (sejenis cacar air). Namu ada juga yang dikunyah atau dimasukkan beberapa butir dalam gelas kemudian diminum, cara ini sebagai pengobatan penyakit tubuh bagian dalam seperti sakit perut, maag, liver dan tumor (Kurniawan, 2015).

Dari hasil studi pendahuluan beberapa masyarakat Kecematan Woja lebih memilih menggunakan obat tradisional Lo'i Keta daripada kerumah sakit diera pandemi Covid-19 masih banyak masyarakat merasa takut tertular virus Covid-19 walaupun dengan mengikuti protokol kesehatan, untuk pergi berobat kepelayanan kesehatan terutama Rumah Sakit Umum maupun Puskesmas. Berdasarkan latar belakang tersebut peneliti menggambil topik penelitian tentang "Analisis Persepsi Masyarakat Dengan Sikap Memilih Pengobatan Tradisional Lo'i Keta Daripada Ke Rumah Sakit Di Era Pademik Covid-19 Di Kecamatan Woja Kabupaten Dompu"

\section{METODE}

Penelitian ini adalah penelitian kualitatif pada masyarakat Woja Kabupaten Dompu. Penelitian ini diharapkan dapat mengeksplorasi serta memahami makna yang diperoleh dari informan yang berasal dari pengalaman-pengalaman yang disampaikan oleh informan di lokasi penelitian. data yang diperoleh dapat dianalisis dari tema-tema khusus ke tema-tema umum (Creswell, 2013). Waktu pengambilan data 0819 Agustus 2021, menggunakan purposive sample. partisipan penelitian ini berjumlah 15 orang. Partisipan pertama ditentukan berdasarkan dari key

http://jurnalilmiah.stikescitradelima.ac.id/index.php/JI Vol.5 No.2 Januari 2022 
informan dengan kriteria inklusi: Partisipan bersedia menjadi partisipan penelitian sampai selesai, dan masyarakat yang sering menggunakan Lo'i Keta.

Pengumpulan data menggunakan panduan wawancara semi berstruktur, catatan lapangan, dan perekam suara (voice recorder). Prosedur pengumpulan data dengan melakukan proses perizinan penelitian sesuai ketentuan berlaku, melakukan pendekatan membina hubungan saling percaya, menjelaskan informed consent. Wawancara dilakukan sesuai dengan kontrak waktu dan tempat yang disepakati, proses wawancara mendalam dilakukan dengan cara mengajukan pertanyaan terbuka. Durasi wawancara antara 25 sampai 55 menit.

Analisa data menggunakan metode Colaizzi yakni mendeskripsikan makna pengalaman melalui indentifikasi tema penting dengan membaca kembali semua data verbatim hasil wawancara dan catatan lapangan secara berulang-ulang, mereview kembali data serta membuat daftar pertanyaan spesifik, mengartikulasikan makna dari setiap pertanyaan spesifik dan signifikan tersebut dengan memilih kata kunci, mengelompokkan kata kunci kedalam kategori-kategori dan tema-tema, menvalidasi hasil temuan tema-tema kepada partisipan untuk menyusuaikan dengan keadaan yang dialami oleh partisipan sesuai dengan kode etik.

\section{Hasil}

\section{Kembalinya Perilaku Konsumsi Obat Tradisional (Lo'i Keta)}

Masyarakat Bima dan Dompu dan pada umumnya sudah mengenal obat traisional seperti $L o$ ' $i$ Keta sebagai pengobatan tradisional sejak dulu dari nenek moyang mereka, khususnya masyarakat di Kecamatan Woja memiliki kebiasaan menggunakan Lo'i Keta sebagai penanganan pertama masyarakat yang mengalami penyakit ringan hingga penyakit kronis sebelum membawa pada Puskesmas dan Rumah Sakit. Beberapa ungkapan Partisipan:

"Iya sering nak kani Loi Keta, Nami dari Toi-Toi waumu sudah kani bore L'oi Keta ndi Lo'i kai supu" (P5). Terjemahan : (Iya sering menggunakan Loi Keta nak, Kami dari kecil sudah menggunakan Lo' $i$ Keta untuk pengobatan penyakit) (P5). “ceritapu nenek-nenek nami, sudah sejak dari Wai ro Waro nami sudah kani Lo'i keta untuk mengobati supu ro pana"(P13). Terjemahan (dari cerita neneknenek kami, sejak dari nenek moyang kami sudah menggunakan Lo'i Keta untuk pengobatan sakit dan demam ) (P13).

Latar belakang masyarakat Dompu di Kecamatan Woja memilih Lo'i Keta sebagai pengobatan penyakit dipengaruhi oleh keadaan pandemi Virus Corona-19. Masyarakat memilih pengobatan tradisional seperti Lo'i Keta karena masyarakat mudah mendapatkan dan nyaman untuk dilakukan, apalagi keadaan sekarang terjadi pandemi Covid-19. Masyarakat meyakini dengan pengobatan dengan Lo'i Keta dapat memberikan dapat mencegah dan memberi kekebalan pada tubuh sebagai penagkal Covid-19.

Beberapa ungkapan Partsisipan:

"Dari pada nami laomu aka uma sakit, carupu nono ra bore ta lo’i keta ake ma moda ndiraka"(P11). (Dari pada kami mengobati sakit di Rumah Sakit lebih baik kami gunakan Lo'i Keta yang mudah didapat) (P11).

"Nami dahu lao ta uma saki, karena niki dou ma lao lo'i ta uma saki, hinapu Corona" (P15). (Kami takut pergi pengobatan di Rumah Sakit, karena tiap orang yang berobat, tertular Corona) (P15).

“carupa loi kaimu Lo'i Keta, dari pada ke uma sakit hina walipu Corona"(P7). (lebih baik gunakan Lo'i Keta, dari pada pengobatan di rumah sakit tertular Virus Corona) (P7).

Masyarakat memilih pengobatan tradisional Lo' $i$ Keta disebabkan keadaan pandemi Covid-19. Masyarakat mendapat informasi bahwa banyak yang tertular Covid-19 di rumah sakit sehingga masyarakat memilih pengobatan tradisional yang sering digunakan dan sudah terbukti khasiat kegunaannya dari terun temurun sejak nenek moyang. masyarakat mengenal pengobatan tradisional Lo'i Keta dapat meningkatkan imunitas dan kekebalan tubuh, maka dari itu tren penggunaan Lo'i Keta pada masyarakat meningkat disaat Pandemi Covid-19.

\section{Pemanfaatan pengobatan Tradisional (Lo $\boldsymbol{i}$ Keta)}

Masyarakat memilih menggunakan obat tradisional Lo'i Keta sebagai upaya pencegahan dan pengobatan penyakit diantaranya seperti penyakit

http://jurnalilmiah.stikescitradelima.ac.id/index.php/JI Vol.5 No.2 Januari 2022 
kulit, bisul (Furunkel), cacat air (varicella), Gastritis, Liver, Cancer dan demam. serta meningkatkan imunitas antibodi tubuh. Beberapa ungkapan partisipan:

"Lo'i Keta ake biasanya nami kani untuk bore kai kadi ra mposo"(P1). (Lo'i Keta biasanya kami gunakan untuk mengobati gatal-gatal dan bisul) (P1).

"Wara si pana sarumbu ra rome ade nami ma kani lalopa Lo'i Keta, awu walipu ake wunga corona"(P4). (jika badan lemas dan demam kami gunakan Lo'i Keta, apalagi sekarang Corona) (P4).

"Wara si pili loko ra la wili, biasanya nahu nono lalo Lo'i Keta na sana lalopa iyuku”(P8). (jika sakit perut dan ulu hati, saya langsung minum Lo'i Keta, setelah itu reda sakitnya) (P8).

"nami rau kani Lo'i Keta wara si ma winte ade sarumbu bune winte ra mbaa susu"(P9). (kami gunakan juga Lo'i Keta untuk di baluri pada luka dan bengakak payudara)(9).

Berdasarkan pengalaman masyarakat penggunaan pengobatan Lo'i Keta dapat mencegah dan menyembuhkan Demam, penyakit kulit, Gastritis, Liver dan Cancer serta imunitas tubuh. Data keluhan dan gangguan kesehatan partisipan diketahui karena sebelumnya partisipan sudah melakukan memeriksakan dan pengobatan di Rumah Sakit maupun Puskesmas sehingga mereka sudah mengetahui informasi tentang keluhan sakitnya.

\section{Cara Penggunaan Obat Tradisional (Lo'i Keta)}

Cara penggunaaan pengobatan tradisional $L o{ }^{\prime} i$ Keta dengan dibalurkan pada bagian yang sakit seperti pada bisul, cacar air dengan membalur pada lokasi yang sakit. Adapula penggunaan Lo'i keta dengan cara diminum dengan diaduk dengan air setelah menyatu kemudian diminum. Adapu beberapa ungkapan partisipan:

"Biasana kani Lo'i Keta ku bore lalo ade mposo" (P12). (biasanya Lo'i Keta saya baluri pada lokasi bisul) (P12).

"Lo'i dekai ta isi loko re nami campo kai oi nggori ede nono kampoi lalo sagala"(p15). (Pengobatan bagian area didalam perut kami mengaduk dengan air satu gelas kemudian di minum) (P15).

Pengobatan obat Lo'i Keta berdasarkan kebiasaan masyarakat dengan cara dibaluri pada area yang sakit dan di minum. Pengobatan dengan cara membalur diperuntukan pada penyakit di area terbuka seperti bisul, cacar air, cancer sedangkan cara diminum di peruntukan untuk penyakit Gastristritis, Liver dll.

\section{Pembahasan}

\section{Kembalinya Perilaku Konsumsi Obat Tradisional (Lo'i Keta)}

Indonesia adalah Mega Center keaneka ragaman hayati yang belum dimanfaatkan secara maksimal, Indonesia kaya akan tradisi baik tertulis maupun tradisi turun temurun disampaikan secara lisan oleh nenek moyang. Perkembangan jaman dan teknologi membuat pemanfaatan obat tradisional kian berkurang. Masyarakat cenderung menggunakan obat kimia yang khasiatnya lebih cepat untuk mengobati penyakit yang diderita. Hal ini menyebabkan kebiasaan meminum obat trasional mulai menurun, bahkan generasi muda sudah jarang yang minum obat tradisional. Alasanya, rasanya kurang disukai, juga terjadi perubahan gaya hidup, tingkat ekonomi dan selera masyarakat (Dharwiyanto Putro, 2018). Namun, kebiasaan masyarakat di tengah pandemi Covid-19 saat ini sudah berubah, menyebabkan masyarakat mencari berbagai alternatif untuk mencegah infeksi Covid-19.

Usaha masyarakat dalam mencari pencegahan pengobatan saat pandemi Covid-19 telah membawa mereka dalam berbagai macam proses pilihan perilaku perawatan kesehatan. Sumber informasi dan berita sangat membantu masyarakat untuk mendapatkan alternatif pengobatan saat pandemi Covid-19 (Dharwiyanto Putro, 2018). Alternatif pengobatan masyarakat Woja saat Pandemi Covid-19 yaitu beralih pada pengobatan tradisional Lo'i Keta. Istilah Lo'i Keta merupakan obat tradisional berbentuk serbuk berwarna ungu yang bersumber dari racikan bahan rempah-rempah yang dapat meningkat antibodi sebagai pencegahan dan pengobatan sakit pada masyarakat suku Bima dan Dompu (Kurniawan, 2015).

Masyarakat Kecamatan Woja mengenal Lo'i Keta sebagai obat tradisional. Lo'i Keta dimanfaatkan oleh masyarakat Bima Dompu turun temurun dari generasi ke generasi sebagai pengobatan penyakit ringan hingga penyakit kronis. Saat Pendemi Covid19 pilihan masyarakat makin meningkat 
menggunakan Loi Keta untuk menjaga imunitas tubuh sebagai upaya pencegahan tertular Covid-19 yang sedang merebak. Masyarakat akan kembali menggunakan obat tradisional sebagai alternatif pengaobatan apabila belum ditemukan suatu obat terhadap suatu penyakit (Kusumo et al., 2020).

\section{Pemanfaatan Pengobatan Tradisional (Lo'i Keta)}

Lo'i keta merupakan obat bahan alam yang ramuan, cara pembuatan, khasiat, keamanan dan cara penggunaanya berdasarkan pengalaman tradisional penduduk Bima Dompu, khususnya Kecamatan Woja sudah merasakan manfaat dan khasiat dari Lo'i Keta. Hasil wawancara masyarakat Wajo mengungkapkan pemanfaatan obat tradisional Lo'i Keta sebagai pencegahan dan pengobatan penyakit kulit, bisul (Furunkel), cacat air (varicella), Gastritis, Liver, Cancer dan demam serta meningkat imunitas antobodi. Hasil wawancancara Zulkarnain dan istrinya Asmah warga Nowa Kecamatan Woja Kabupaten Dompu bahwa Loi Keta berasal dari rempah-rempah terbuat dari tepung beras ketan putih, beras merah, ketan hitam, kulit pohon duwet, daun bidara, bunga, buah dan daun delima, bunga pacar, wunta (bunga) parmau keta, wunta mundu, daun katu, kulit manggis, wunta kenanga, dan lainnya (Anonim, 2019). Berdasarkan komposisi pembuatan Lo'i Keta berasal dari biji-bijian, daun, bunga dan kulit tumbuh-tumbuhan yang kaya kandungan senyawa antioksidan. Senyawa antioksidan tersebar pada bagian tumbuhan mulai dari akar, batang, kulit, daun, bunga, buah dan biji (Langgori \& Kistiani, 2021).

Antioksiadan berperan penting dalam sistem pertahanan organisme melawan keruskan radikal bebas dan mempertahankan kesehatan yang optimal. Pemanfaatan antioksidan jangka panjang mampu mengurangi berbagai macam penyakit dan memberikan efek yang baik pada kesehatan (Handiani, 2019). Dengan demikian, Lo’i Keta yang merupakan obat tradisional berasal dari rempahrempah yang kaya kandungan antioksidan dapat menangkal radikal bebas, memberikan kekebalan tubuh, dan memberikan perlindungan terhadap penyakit ringan maupun penyakit kronis.

Masyarakat Wajo meyakini pemanfaatan $L o^{\prime} i$ Keta sangat membantu dalam pencegahan dan pengobatan saat pandemi Covid-19, selain dapat meningkat imunitas tubuh juga dapat mengobati berbagai macam penyakit. Berdasarkan pengalaman masyarakat Wajo Lo'i Keta diyakini pilihan yang tepat dan aman dalam mencegah dan mengobati berbagai macam penyakit ringan hingga penyakit kronis saat pandemi Covid-19.

\section{Cara Penggunaan Obat Tradisional (Lo'i Keta)}

Cara penggunaan Lo'i Keta berdasarkan dengan penyakit yang diobati, Partisipan menyatakan penggunaan Lo'i Keta dapat dilakukan dengan dua cara yaitu: diminum atau dikunyah dan dibaluri pada lokasi yang sakit. Cara pertama diminum dengan mencampurkan Lo'i Keta dengan air hangat satu gelas kemudian mengaduk kemudian meminum. Masyarakat meyakini penggunaan obat di minum dapat menyembuhkan penyakit dalam secara langsung seperti sakit gastritis dan liver. Penelitian lain menyatakan penggunaaan obat dengan cara diminum lebih banyak dimanfaatkan oleh masyarakat karena dipercaya dapat mengobati secara langsung pada penyakit dalam (Syah \& Yusro, 2014).

Cara penggunaan Lo'i Keta yang kedua dengan membaluri Lo'i Keta pada area tubuh yang sakit secara merata. Cara ini diyakini masyarakat dapat mengobati penyakit pada anggota badan bagian luar seperti penyakit gatal-gatal, bisul, luka, benjolan dll. Penelitian lain menyatakan umumnya pengobatan luar dengan cara dibaluri pada bagian tubuh yang sakit secara langsung (Wulandara, F. D., \& Rafdinal, L. R, 2018).

\section{Kesimpulan}

Lo'i Keta merupakan obat tradisional masyarakat yang di yakini dapat meningkatkan antibodi tubuh dalam pencegahan dan pengobatan penyakit. Saat pandemi Covid-19 menyerembak, Lo'i Keta menjadi alternatif pengobatan masyarakat karena mudah didapat dan aman digunakan. Pemanfaatan Lo'i Keta diyakini masyarakat untuk mencegah dan mengobati penyakit kulit, bisul (Furunkel), cacat air (varicella), Gastritis, Liver, Cancer dan demam serta meningkat imunitas antobodi tubuh. Cara penggunaan Lo'i Keta diminum atau dikunyah dan dibaluri pada lokasi yang sakit.

http://jurnalilmiah.stikescitradelima.ac.id/index.php/JI Vol.5 No.2 Januari 2022 


\section{DAFTAR PUSTAKA}

Adventus, Merta Jaya, I. M., \& Hendra, D. (2019). Buku Ajar Promosi Kesehatan. Jakarta.

Anonim. (2019). Loi Keta, Obat Berkhasiat Warisan leluhur. Lensa Pos. http://www.koranlensapos.com/2019/06/loiketa-obat-berkhasiat-warisan-leluhur.html.

Creswell, J. W. (2013). Research Design_ Qualitative, Quantitative, and Mixed Methods Approaches-SAGE Publications, Inc (2013).epub. SAGE Publications, Inc.

Dharwiyanto Putro, B. (2018). Persepsi dan Perilaku Pengobatan Tradisional Sebagai Alternatif Upaya Mereduksi Penyakit Tidak Menular. Sunari Penjor: Journal of Anthropology.

Handiani, F. (2019). Oksidan dan antioksidan pada beberapa penyakit dan proses penuaan. Zifatama Jawara.

Kurniawan. (2015). MANTRA LO'I KETA MASYARAKAT BIMA: KAJIAN SEMIOTIKA RIFFATERRE DAN RELEVANSINYA DENGAN PEMBELAJARAN KEBUTUHAN DASAR MANUSIA I DI SMK KESEHATAN YAHYA. Litera Jurnal Bahasa dan Sastra.

Kusumo, A. R., Wiyoga, F. Y., Perdana, H. P., Khairunnisa, I., Suhandi, R. I., \& Prastika, S. S. (2020). JAMU TRADISIONAL INDONESIA: TINGKATKAN IMUNITAS TUBUH SECARA ALAMI SELAMA
PANDEMI. Jurnal Layanan Masyarakat (Journal of Public Services), 4(2), 465. https://doi.org/10.20473/jlm.v4i2.2020.465471.

Langgori, J. A. P., \& Kistiani, E. B. E. (2021). Kandungan Senyawa Antioksidan Pada Biji, Kulit Buah, Dan Buah Pinanga Ceasea Blume. SINASIS (Seminar Nasional Sains).

Nelson, N. C. (2018). Model Behavior: Animal Experiments, Complexity, and the Genetics of Psychiatric Disorders. University of Chicago Press.

https://doi.org/10.7208/chicago/9780226546 117.001 .0001

Purnama, Y. (2016). Kearifan Lokal Masyarakat Jatigede Dalam Pengobatan Tradisional, THE LOCAL WISDOM OF JATIGEDE COMMUNITY IN TRADITIONAL MEDICINE. Patanjala.

Syah, J. ,. Usman, F. H. ,., \& Yusro, F. (2014). Ethnobotany Study of Medicinal Plants in Nekbare Village Samalantan District Bengkayang Regency. Jurnal Hutan Lestari, 2(3).

Wulandara, F. D., \& Rafdinal, L. R. (2018). Etnobotani Tumbuhan Obat Suku Melayu Desa Durian Sebatang Kecamatan Seponti Kabupaten Kayong Utara. J Protobiont, 7(3), 36-46.

http://jurnalilmiah.stikescitradelima.ac.id/index.php/JI Vol.5 No.2 Januari 2022 